\title{
DEKONSTRUKSI WAYANG DALAM NOVEL DURGA UMAYI
}

\author{
Mashuri \\ Balai Bahasa Surabaya \\ Jl. Siwalanpanji, Buduran, Sidoarjo \\ Email: misterhuri@gmail.com
}

\begin{abstract}
Abstrak
Kajian ini adalah ikhtiar mengidentifikasi perayaan pembacaan dalam novel Durga Umayi karya Y.B. Mangunwijaya, terbit tahun 1991. Pendekatannya menggunakan 'cara baca' dekonstruksi. Fokus kajiannya pada diskursus wayang yang cukup dominan dalam karya yang terbit pada 1991 ini. Tujuannya, menggali hal-ihwal di balik 'teks' wayang dalam novel. Ternyata terdapat begitu banyak pembongkaran pada konstruksi wayang yang mapan, dan terbukti dengan adanya banyaknya 'jejak' teks yang dibaca kembali dengan perspektif tak tunggal, kontradiksi tokoh, pengaburan fakta-fiksi, serta pembalikan nilai-nilai dan oposisi biner lainnya. Konsepsi pengaburan dan pembalikan oposisi biner dalam novel ini diformulasikan menjadi semacam senyawa eksperimental sehingga terjadi 'decentering', peniadaaan pusat (pusat yang menyebar).
\end{abstract}

Kata kunci: wayang, dekonstruksi, novel

\section{Abstract}

This study is a summary of reading celebration in effort to identify novel Durga Umayi written by YB Mangunwijaya, published in 1991. The approach used 'reading' of' deconstruction. Study focuses on the puppet which is the dominant discourse in the novel that was published in 1991. The goal of the study is finding the events bebind the 'text' puppet in the novel. Apparently there are so many demolition on puppet construction are well established, and proved by the number of 'trace' the text read back with no single perspective, contradictory figure, blurring the factfiction, as well as the reversal of values and other binary opposition. The blurring and inversion conception of binary opposition in this novel is formulated as experimental element that causes 'decentering' (center spread).

Keywords: puppet, deconstruction, novel

\section{Pendahuluan}

Sebuah teks sastra memiliki korelasi dan keterkaitan dengan teks lain. Hal itu karena sastra sebagai mozaik teks tidak tercipta dari kekosongan budaya (Teeuw, 1980: 11). Dapat pula dikatakan, sebuah teks sastra merupakan "sikap" terhadap teks-teks lain. Sikap tersebut bisa diartikan sebagai tanggapan, jawaban, kritikan atau kompromi yang mengarah kepada representasi keberagaman dan pemaknaan yang tidak tunggal dan final. Hal itu dikarenakan hakekat sastra merupakan ketegangan yang terus-menerus antara konvensi-konstruksi teks-teks terdahulu-dengan inovasi (Teeuw, 1980: 12). Inovasi yang dimaksud merupakan usaha konstruktif untuk menyempurnakan atau mereaktualisasi dari konvensi yang ada, agar dunia ideal dapat terbentuk dari proses kreatif yang terus-menerus.
Novel Durga Umayi (Grafiti, 1991), novel karya Y.B. Mangunwijaya memiliki kecenderungan besar ke arah tersebut. Novel ini juga mempunyai kekhasan tersendiri sebagai produk dari sastra Indonesia modern. Dengan asumsi bahwa novel ini merupakan hasil dari dialektika teks-teks, dan merupakan inovasi terhadap konvensi novel-novel Indonesia sebelumnya. Kekhasan dari novel Durga Umayi yang terbagi dalam dua bagian, yaitu "Prawayang" (xi halaman) dan "isi" (188 halaman) ini, tidak hanya pada struktur teksnya saja. Dari segi bahasa dan penceritaannya juga berbeda dari novel-novel Indonesia pada umumnya. Begitu pula dari segi "isi", terdapat kekhasan lain. Di antaranya, novel ini memuat kontradiksi-kontradiksi yang mengisyaratkan sebuah perlawanan terhadap kondisi kemapanan dari sebuah konstruksi atau sistem kultural. Dapat pula dikatakan bahwa novel ini mengarah kepada usaha pembongkaran 
konstruksi-konstruksi yang sudah mapan, seperti pada konvensi wayang, yakni dari kisah berubahnya Dewi Uma menjadi Batari Durga, menjadi aspek yang dilematis antara unsur Uma dan Durga dalam satu pribadi, dalam hal ini pada diri tokoh utamanya. Di samping itu, ada juga pengaburan terhadap oposisi biner, antara Dewi Uma yang cantik dan representasi karakter baik, dengan Durga yang buruk dan berwatak jahat. Bertitik tolak dari asumsi dasar tersebut, kajian ini menitikberatkan pada teks-teks dekonstruktif yang terdapat dalam novel Durga Umayi terutama teks-teks wayang. Penelaahannya bertolak dari kapasitas teks, sebab teks dekonstruktif dalam novel ini merupakan unsur pembentuk teks novel yang dominan.

Di sisi lain, Durga Umayi menggunakan kalimat-kalimat panjang, mempunyai kecenderungan ke arah novel posmodern. Hal ini juga merupakan alasan dipilihnya Durga Umayi sebagai obyek kajian. Di antara ciri novel-novel postmodern yaitu; "dunia" yang semestinya diciptakan dalam cerita, dihapuskan, dan yang diutamakan adalah kata-kata (Allen, 1996: 101-119). Kecenderungan ini dalam Durga Umayi perlu disangsikan karena dalam Durga Umayi, "dunia" masih tercipta di antara susunan kata-katanya yang melimpah. Jadi Durga Umayi tidak melulu mengutamakan katakata, tetapi juga makna di balik kata-katanya itu, serta simbol-simbol dari sistem tanda yang ada.

Menurut Allen, ciri-ciri lain dari novel posmodern adalah adanya persepsi maksud tersembunyi, persepsi dualisme, pengaburan, penjungkirbalikan, persilatan kata-kata, ketidakberkaitan antarkata, lebih bersifat writerly (latihan menulis) daripada readerly (untuk dibaca). Adapun gaya penulisan dalan Durga Umayi juga menggunakan cara-cara penulisan novel postmodern. Di antaranya, adanya kontradiksi, ekses, lebih mengutamakan penanda (signifier) daripada petanda (signified), serta banyaknya heteroglosia (Allen, 1996: 101). Hal itu tidak banyak dijumpai dalam novel Indonesia seperiode. Meski demikian dengan perspektif yang berbeda, Pujiharto telah menemukan kemunculan puitika pascamodernisme dalam fiksi Indonesia, yaitu puitika ontologis. Munculnya puitika tersebut ditengarai dari perubahan yang dominan dari dominan fiksi modern ke dominan ontologis fiksi posmodern dan itu tampak pada beberapa fiksi Putu Wijaya, Danarto dan Seno Gumira Ajidarma. (Pujiharto, 2010: 433)

Yang perlu digarisbawahi, walaupun dalam beberapa hal Durga Umayi berkecenderungan sesuai dengan ciri-ciri novel posmodern, tetapi Durga Umayi bukan hanya sekedar novel dengan banyaknya heteroglosia dan kata-kata yang melimpah semata. Durga Umayi masih menyisakan 'ruang makna' meski sebenarnya ruang itu terbentuk dari 'permainan' sistem tanda yang terangkum di dalamnya. Begitu pula dengan "dunia" dalam Durga Umayi yang seharusnya dihilangkandalam batasan novel posmodern-masih tercipta dan merupakan susunan mozaik dari teks-teks yang berjalin-kelindan dan beragam. Akibatnya, kepostmodernan Durga Umayi sepertinya berbeda dengan konvensi novel posmodern yang secara an sich telah digariskan atau disepakati oleh para kritikus sastra 'Barat', sebagaimana pemerian McHale. (1991: 11)

Oleh karena itu, penelitian ini dibatasi pada ikhtiar pelacakan “jejak-jejak” teks lain, yang merupakan konstruksi lama yang terdapat dan mewarnai dalam konstruksi teks baru, yaitu Durga Umayi, dengan fokus pada dekonstruksi wayang dengan operasionalisasi pada pelacakan ‘jejak', kontradiksi tokoh dan pengaburan faktafiksi, serta pengaburan nilai-nilai dan oposisi biner lainnya. Konsepsi pengaburan oposisi biner dalam novel ini diformulasikan menjadi semacam senyawa eksperimental sehingga terjadi 'decentering' atau peniadaaan pusat dan pembalikan-pembalikan. Kajian ini adalah ikhtiar mengidentifikasi perayaan pembacaan yang terdapat dalam teks-teks Durga Umayi, terutama pada pembongkaran diskursus wayangnya. 


\section{Membongkar Sakralitas Wayang dalam Durga Umayi}

Dalam ranah budaya Jawa, wayang menempati posisi penting, sentral sekaligus sakral. Ajaran Jawa tentang etika atau ajaran kehidupan, bersumber dari nilai-nilai yang terkandung dalam wayang, baik itu epos Mahabarata maupun Ramayana. Ajaranajaran ini menyangkut ajaran sosial, kebaikankeburukan dan spiritualitas. Dalam kisahkisah yang tertuang di wayang merupakan rajutan kisah-kisah yang sarat nilai dengan mengandaikan kehidupan manusia di dunia yang dijalankan dengan penuh perimbangan dan harmoni, dengan kisah perjalanan tokohtokoh wayang. Intinya wayang merupakan identitas utama manusia Jawa (Sujamto, 1995: 19).

Realitas itu dikukuhkan dalam khasanah-khasanah Jawa tempo dulu. Banyak para pujangga Jawa, baik itu dalam Jawa Kuno maupun dalam Jawa Pertengahan, menggubah sekaligus menyadur Ramayana dan Mahabharata. Umumnya tokoh-tokoh wayang itu diidentikkan pada diri sang raja yang dianggap sebagai titisan dewa, seperti yang dilakukan Mpu Kanwa, dengan mengabadikan Prabu Airlangga dalam Kakawin Arjunawiwaha. Prabu Airlangga dianggap sebagai personifikasi dari sosok Arjuna, yang melakukan tapa-brata menuju kesempurnaan. Posisi kesucian dan sakralitas memang selalu identik dalam wayang, tidak heran banyak tokoh yang mencoba menemukan dirinya dalam kesucian tokohtokoh yang digambarkan dalam wayang. Bisa jadi karena wayang dianggap sebagai sebuah produk budaya yang sangat tua, sebagaimana yang ditegaskan Brandes, bahwa wayang merupakan salah satu dari sepuluh budaya tinggi yang telah dimiliki bangsa Indonesia sebelum budaya Hindu berpengaruh di Nusantara (Koentjaraningrat, 1958: 455).

Dalam cerita seputar Durga Umayi yang dalam khasanah lama berserak dalam beberapa serat dan suluk seperti Nitimani, Kama Salah, Kidung Sudamala dan lain sebagainya, yang menganggap bahwa lakon ini tidak hanya cerita biasa. Lebih jelasnya dalam Serat Pusatakaraja Parwa, gubahan R. Ng. Ronggowarsito, mengisahkan kelahiran Batara Kala, sekaligus perubahan Dewi Uma menjadi Batari Durga sebagai sebuah bencana dan tragedi. Dalam konteks itu, cerita tersebut adalah salah satu sarana untuk melepaskannya, dengan cara diruwat. Artinya cerita tersebut dijadikan sebagai sarana untuk melepaskan sengkala atau kesialan. Pertunjukkan wayang itu pun identik dengan sakralitas dan penyucian. Selain itu, harus disertakan ubo rampe dan sesajen yang menyiratkan bahwa pertunjukan itu memang tidak hanya pertunjukan wayang tetapi suatu upacara atau ritual sakral. Ihwal lakon ruwatan ini akan dibahas lebih jauh dalam sub-bab tersendiri.

Nilai-nilai kesakralan yang dijunjung tinggi dalam kultur Jawa itu-baik dalam pertunjukan wayang biasa maupun dalam rangka ruwatan-hampir tidak tertemukan penyajiannya dalam teks Durga Umayi. Banyak teks yang membongkar kesakralan wayang; salah satunya dengan cara profanisasi. Profanisasi terjadi tidak hanya terhadap tokoh wayang yang dianggap sakral dan pusat teladan tetapi juga pada esensi dari jalan cerita serta nilai-nilainya. Teks-teks pembongkaran itu sepertinya sengaja dihadirkan untuk menandingi diskursus wayang yang sudah terbentuk dan mapan.

Berkaitan dengan pengaburan oposisi biner dengan tendensi profanisasi wayang, dalam konteks ini, menyangkut kisah wayang yang bercerita mengenai kisah Batara Guru beserta Dewi Uma, istrinya, serta kisah berubahnya Dewi Uma menjadi Batari Durga. Dalam beberapa teks dijumpai nada menghujat dan meremehkan Batara Guru. Meski dalam beberapa hal Batara Guru di sini direduksi dalam penafsiran yang lebih general dengan mengacu pada konsepsi humanis yang menunjukkan kondisi 'batin' manusia.

Dalam wayang konvensional, Batara Guru dipahami sebagai dewa yang sakral, penguasa alam raya. Dalam Durga Umayi, Batara Guru dipahami sebagai manusia biasa, seorang laki-laki (Jawa). Malah, dengan gaya tutur yang 
cukup sarkas, dinyatakan Batara Guru sebagai dewa tetapi tidak bisa mengekang nafsunya untuk bersenggama dengan istrinya, Dewi Uma, di atas pelangi dengan menunggang Lembu Andini. Disebutkan Batara Guru hanya menuruti hasrat kelelakiannya, dengan menghubungkan perilaku Batara Guru itu dengan sifat kebiasaaan lelaki Jawa. Teksnya adalah:

"(Iin) merana hilang alas serasa dalam lumpur rawa-rawa kutukan Batara Guru yang sama sekali bukan guru melainkan taring babi-hutan belaka yang tidak senonoh namun celakanya dewa yang kuasa dan tahu dia kuasa dengan seronok kenikmatan jorok yang sengak" (Mangunwijaya, 1991: 105).

"Ah memang lelaki itu Batara Guru sifatnya, paling tidak lelaki Jawa, tetapi boleh jadi semua lelaki begitu" (Mangunwijaya, 1991: 119).

"Karena lelaki memiliki hak istimewa dari Batara Guru tidak pernah kehilangan keperawanannya, biar menjadi pispot sekalipun yang sudah bocor karena terlalu banyak dipakai di pelacuran kota Makao yang paling jorok" (Mangunwijaya, 1991: 121).

Hardjowirogo menyebutkan, Batara Guru merupakan dewa yang sangat berkuasa, karena kesaktian dan ketampanannya. Ia putra Hyang Tunggal dan dilahirkan berupa cahaya. Dalam dunia mistifikasi Jawa, wayang Batara Guru sangat dihormati dan dianggap sebagai wayang yang paling keramat. Oleh karena itu, wayang Batara Guru dibedakan dengan wayang-wayang lainnya. Salah satunya, di antara wayang-wayang yang ada, hanya wayang Batara Gurulah yang diselubungi dengan kain indah. Sebelum dimainkan, wayang itu dikenakan asap dupa terlebih dulu dan orang-orang pun takut melangkahi batang pisang bekas menancapkan wayang Batara Guru. Dalam memainkannya juga demikian, ketika sedang dimainkan oleh dalang, selalu diiringi dengan bunyi gamelan yang merdu (Hardjowirogo, 1989: 35-7).

Dalam teks-teks Durga Umayi, kesakralan tokoh Batara Guru, yang dalam beberapa hal disakralkan, baik dari segi esensi maupun eksistensinya, dibongkar habishabisan. Dengan memberi penekanan pada perilakunya yang tidak senonoh berkaitan dengan nafsu birahinya. Padahal dalam budaya Jawa, Batara Guru dipahami sebagai tamsil dari halusnya batin manusia. Meski demikian, esensi keagungan yang lebih mengedepankan aspek spiritual itu sama sekali tidak ditampakkan dalam bingkai teks-teks Durga Umayi.

Selain itu gambar tokoh wayang Batara Guru, tidak disertakan dalam parade tokoh-tokoh wayang yang terpampang dalam novel Durga Umayi. Bisa jadi, dengan tidak menghadirkannya dalam perwujudan gambar maka usaha untuk melucuti dan membongkar konstruksi mapannya dapat berjalan dalam pretensi tanpa batas, atau dalam bayang-bayang ambiguitas mitosnya. Hal itu karena perilaku Batara Guru seperti yang digambarkan dalam Prawayang, yang mengacu pada mitologi wayang secara an sich dianggap sebagai perilaku yang lumrah dan tidak melanggar etika karena Batara Guru adalah dewa yang dianggap sebagai penguasa Ngarcapada, dan semua perilakunya tidak bercela dan semua makhluk di dunia takluk kepadanya.

Tokoh wayang lainnya yang juga mengalami proses profanisasi adalah Gatotkaca. Terdapat banyak teks yang menyerang sekaligus menetralisir tokoh ini ke posisi 'tak istimewa'. Dalam teks digambarkan, Gatotkaca sebagai laki-laki yang kelakuan atau sifatnya hanya bisa 'terbang melulu'. Arah dari penyebutan sedemikian rupa dengan jelas pada kaidah wacana seks. Teksnya: "Maklumlah lelaki itu banyak yang hebat ganteng seperti Gatotkaca tetapi ya sukanya terbang melulu dan berkelahi." (Mangunwijaya, 1991: 37) Pereduksian yang radikal dari tokoh Gatotkaca ke dalam wacana seks seakan-akan melemahkan kelebihan atau kesaktian sang tokoh, yang dalam pewayangan digambarkan mempunyai kemampuan bermacam-macam, di antaranya mampu untuk terbang mengangkasa.

Dalam wayang konvensional, 
Gatotkaca merupakan tokoh yang disegani sekaligus diidolakan dan diteladani banyak orang karena berkaitan dengan kelebihankelebihan, keistimewaaan dan kesaktiannya. Gatotkaca merupakan putera Bima dengan ibu Dewi Arimbi, seorang putri raja raksasa. Sehingga waktu dilahirkan, ia berwujud raksasa. Konon, karena saktinya, tali pusarnya tidak bisa dipotong dengan pusaka apapun, kecuali dengan senjata Kunta milik Raden Karna. Gatotkaca merupakan kekasih dewa yang bertahta di kahyangan, sehingga sering dihadiahi bendabenda pusaka, seperti Terompah Padakacarma, Tutup Kepala Basunanda dan Kutang Antakusuma. Ia terkenal sakti mandraguna dengan sebutan ksatria berotot kawat bertulang besi (Hardjowirogo, 1989: 183).

Adapun realitas sosio-kultural dalam memandang sosok Gatotkaca memang tidak terlepas dari pandangan yang penuh keagungan. Pandangan itu hingga kini telah terabadikan dalam arketipe-artketipe budaya Jawa. Misalnya, dengan adanya nama sebuah benda keramat di Demak yang bernama Kutang Antakusumo. Kutang ini dianggap sebagai peninggalan Sunan Kalijaga, penyebar Islam di Demak. Nama Antakusumo tidak lain diambil dari baju milik Gatotkaca. Selain Kutang Antakusumo, piranti lain dari Gatotkaca yaitu mengenai nama-nama kekuatannya atau kesaktiannya. Hal ini terabadikan dalam bentuk kekuatan atau nama-nama kesaktian yang hebat dan dahsyat dalam masyarakat Jawa. Dalam Kitab-kitab primbon terdapat nama-nama aji-aji seperti $A j i$ Brajamusti atau Aji Brajalamatan. Kedua nama aji itu bagi masyarakat Jawa, merupakan ajian tingkat tinggi, yang berkekuatan dahsyat. Hal itu tidak lain dari bentuk kekuatan Gatotkaca.

Dalam Durga Umayi terdapat teks yang menempatkan posisi Gatotkaca, lebih rendah daripada punokawan: Petruk, Gareng dan Bagong. Teksnya sangat verbal menyatakan perbandingan antara Gatotkaca dengan para punokawan, dengan memberi penekanan untuk lebih memihak dan memilih pada punokawan. Padahal dalam wayang konvensional, posisi keduanya itu tidak dapat dibandingkan karena punokawan dipahami sebagai tokoh sampingan dan selalu mengabdi pada keluarga Pandawa, termasuk pada Gatotkaca. Dalam hal ini berlaku konsep pembalikan. Posisi yang istimewa (previliese) tidak lagi distimewakan kedudukan dan perannya.

"Maklumlah lelaki itu banyak yang hebat ganteng seperti Gatotkaca tetapi ya sukanya terbang melulu dan berkelahi, maka pilihlah model Gareng atau Petruk atau Bagong sajalah yang biar badut rupanya tidak bermutu tetapi seumur hidup hanya gelak ketawa pahalanya tanpa harus jaga gengsi, sebab gengsi itu mahal juga, jangan dikira di dunia ini ada barang yang gratis dan hadiah belaka" (Mangunwijaya, 1991: 37).

Begitu pula dengan tokoh wayang Dewi Wara Srikandi yang sering dikenal dengan Srikandi saja. Jika berkaitan dengan tokoh utama Iin, dalam salah satu episode, Srikandi lebih dipahami dan ditarik ke dalam wacana seksisme dan terkesan ada sesuatu yang terkesan 'meremehkan', tidak mengacu pada kegagahannya atau kepahlawanannya. Jika merunut pada strategi dekonstruksi, ada maksud tersembunyi dari teks tersebut, karena dalam kisah wayang purwa, Srikandi adalah pahlawan perang Pandawa pada Perang Baratayudha. Dialah yang berhasil membunuh Bisma, panglima perang Kurawa, sekaligus moyang Pandawa dan Kurawa. Mengenai kisah tersebut termaktub dengan jelas pada pakem pedalangan dengan lakon Bisma Gugur. Pereduksian diri Srikandi itu semakin sempurna, apalagi bahasa yang digunakan dalam teks lebih mengarah pada bahasa plesetan.

Dikisahkan setelah Iin ikut laskar wanita, Iin disamakan dengan sosok Srikandi. Dalam perkembangannya sebutan yang diperolehnya itu mengalami perubahan dari Srikandi menjadi Sri Kendi. Sebutan itu berawal karena ukuran payudara Iin sebesar kendi (tempat air untuk minum yang terbuat dari tanah liat atau jenis tembikar). Sebuah plesetan yang memiliki strategi tekstual untuk memberi ruang penafsiran yang lain terhadap sosok ini karena Srikandi 
dalam wayang digambarkan identik dengan kelelakiannya, dan dikenal sebagai prajurit atau ksatria wanita (Hardjowirogo, 1989: 99). Adapun teksnya adalah sebagai berikut:

"Ya mereka menghargai menghormati anak Sersan mayor Obrus yang Srikandi itu tetapi tidak dapat mengekang nafsu untuk memberi nama akrab baru kepadanya: Sri Kendi, menyindir dua payudaranya yang besar seperti kendikendi tetapi yang toh menghormat tidak pernah mereka jamah, hanya diintip saja kalau dia mandi, ... .Ruparupanya Sri Kendi tidak berkeberatan berfunsi sebagai Dinas Hiburan Sosial di Front asal tidak berpolitik praktis ... . Maka penghargaan mereka kepada Sri Kendi tetap utuh jangan diragukan, tetapi ya salah siapa ke mana-mana kok membawa kendi-kendi dan ditutupi malahan menimbulkan ingin tahu, tetapi sungguh mereka menghargai anak di Obrus itu" (Mangunwijaya, 1991: 59).

\section{Tokoh-tokoh Durga Umayi: Pengaburan Fakta-Fiksi}

Dalam Durga Umayi, secara verbal, terdapat beberapa tokoh yang diperbandingkan dengan tokoh-tokoh wayang. Malah dalam beberapa bagian selalu identik dengan tokoh wayang itu, baik itu berlaku untuk tokoh 'nyata' maupun tokoh fiksi. Perbandingannya tidak sekedar dengan ungkapan verbal tetapi mengenai esensi jiwa tokoh tersebut, terutama untuk tokoh utamanya, Iin.

Tokoh Durga Umayi yang memiliki acuan tokoh 'nyata' yang secara verbal diperbandingkan dengan wayang, adalah tokoh sejarah Indonesia, seperti Bung Karno dan Bung Hatta. Dalam salah satu teks, Bung Karno diandaikan seperti Arjuna. "Sebab Bung Karno yang Arjuna”. (Mangunwijaya, 1991: 83) Dalam wayang purwo, Arjuna dikenal sebagai anak ketiga keluarga Pandudewanata (Pandawa). Arjuna berwajah tampan dan digandrungi perempuan. Istrinya banyak. Ada juga yang menyifatinya sebagai lelaki doyan perempuan. Pengandaian dalam teks tersebut bukanlah tanpa pertimbangan. Terdapat beberapa kesesuaian atau kesejajaran antara Bung Karno dan Arjuna. Bung Karno kondang sebagai lelaki tampan yang digandrungi, sekaligus suka 'main' perempuan. Istrinya lebih dari satu. Tercatat sudah ada 9 perempuan yang mengaku sebagai istri resminya. Analogi itu merupakan sebuah strategi teks untuk menguak sekaligus membongkar konsepsi kekuasaan tradisional yang menekankan pada Hasta Brata. Hasta Brata merupakan konsepsi kepemimpinan yang berdasarkan pada 'kearifan budaya' yang bersumber pada lakon wayang Wabyu Makutho Romo. Di sini ditekankan bahwa seorang pemimpin ideal harus memiliki delapan sifat yang merupakan pengejawantahan dewa-dewa (Supadjar, 2001: 290).

Hasta Brata dipahami para pemimpin Jawa sebagai sebuah norma dan tata nilai yang harus dimiliki oleh seorang raja dan calon raja, padahal di dalamnya terdapat kaidah-kaidah tertentu yang tidak sesuai dengan konteks zaman dan harus 'dibaca' kembali. Dalam konteks Durga Umayi, dengan fokus pada sosok Soekarno, ada upaya untuk membongkar konsepsi itu, terutama pada sifat Dewa Candra. Hal itu karena Soekarno cenderung 'mendalami' sifat 'Dewa Candra' yang pandai berolah asmara. Namun yang menarik adalah penggambaran Bung Karno dalam Durga Umayi yang menyaran pada hal-hal kecil, remeh, bahkan cenderung tabu: seperti cara kencing Bung Karno.

Tokoh 'nyata' lain yang diperbandingkan dengan tokoh wayang adalah Bung Hatta. Bung Hatta dalam Durga Umayi diandaikan seperti Yudhistira, nama lain dari Puntodewa. Adapun teksnya: "Dan Bung Hatta yang Yudhistira" (Mangunwijaya, 1991: 83). Yudhistira dalam wayang dikenal sebagai sulung Pandawa dan Raja Astinapura. Ia dikenal sebagai raja yang jujur, tidak pernah berbohong, bertutur kata halus dan seorang ksatria yang rela berkorban. Hal itu termasuk mempertaruhkan istrinya, Dewi Drupadi, ketika berjudi dengan Kurawa, demi menjaga kehormatan saudara-saudara dan ibunya Dewi Kunti. Dalam tataran sifat dan karakter, ada kesamaan antara Bung Hatta 
dengan Yudhistira. Dalam biografi politik Bung Hatta disebutkan beberapa sikap hidup dan sikap berpolitik Bung Hatta yang hampir selaras dengan apa yang diperbuat oleh Yudhistira. Seperti pada momen, ketika Bung Hatta dengan rela dan berbesar hati mengundurkan diri dari kursi wakil presiden, ketika ia tidak setuju dengan sikap politik Bung Karno. Dalam Durga Umayi yang lebih disorot bukan peran besar Bung Hatta, tetapi kebiasaannya sepelesepele. Bahkan pada saat terjadi proklamasi di Pegangsaan Timur, yang digambarkan Durga Umayi adalah soal bagaimana para babu menyiapkan tempat itu, juga gambaran tentang kondisi kamar-mandi, WC dan jemuran keluarga Bung Karno.

Sementara itu, untuk tokoh fiktifnya, baik itu tokoh utama atau tokoh bawahan juga ada yang diandaikan seperti tokoh wayang. Dalam hal ini, yang mendapatkan porsi lebih banyak adalah Iin. Secara verbal, Iin diandaikan pada beberapa tokoh wayang, seakan-akan tokoh wayang itu menjadi bayang-bayang dirinya, atau elemen-elemen yang membentuk kepribadiannya, juga kontradiksi yang menjangkitinya.

Dalam hampir semua konflik batin yang terdapat dalam Durga Umayi yang dialami oleh Iin, hampir seluruhnya mengarah pada dilematis antara Uma dan Durga. Seperti juga pertarungan antara kebaikan dan keburukan dalam diri manusia. Konflik ini akan terjadi terus-menerus dalam prosesnya menjadi manusia dan menghuni Ngarcapada (dunia tengah) ini.

"Pahit karena harus berbuat seperti Batari Durga, dan madu karena unsur Dewi Umayi masih hadir juga, walaupun dalam suatu konflik batin dan kegusaran yang tak pernah dapat diredakan tuntas sepanjang hidup manusia hidup di jagad-tengah ngarcapada antara Kayangan dan Dunia Bawah Tanah." (Mangunwijaya, 1991: 111)

Selain itu, dalam teks lainnya Iin juga diidentikan dengan Srikandi. Hal itu berkaitan dengan sepak terjang Iin, juga karena aspek lelaki dalam pribadi Iin yang lebih besar dari aspek kewanitaannya. Pengidentikan Iin sebagai Srikandi itu pada akhirnya tidaklah terlalu setia pada konsepsi Srikandi dalam wayang Purwa. Malah, mengarah pada penghancuran pada mitos Srikandi itu sendiri, dengan menariknya pada wacana seksis, yang dalam wayang purwa tidak mendapatkan porsinya yang layak, karena yang diekspos hanyalah masalah keprajuritannya. Pembongkaran itu terjadi dengan cara mereduksi nama Srikandi menjadi Sri Kendi atau Si Kendi, seperti pada teks tersebut. Penyebutan Srikandi menjadi Sri Kendi atau Si Kendi itu berkaitan dengan organ fital tubuh Iin-payudara-yang ukurannya sebesar kendi. Bisa pula diartikan sebagai pengembalian posisi Srikandi pada aspek kemanusiaannya, yang berarti aspek kewanitaannya, bahwa ia memiliki semacam kendi. Dalam artian fungsional merupakan tempat menampung air, untuk menghapus dahaga, atau memberi hidup bagi mereka yang membutuhkan. Akan tetapi, dalam bagian yang mendekati akhir dalam Durga Umayi, Iin mendapatkan predikat Srikandi kembali, tanpa embel-embel Sri Kendi atau Si Kendi. Teksnya:

"Dan karena tidak tega melihat penderitaan perwira itu si Kendi langsung memenggal leher Gurka yang masih muda dan tampan itu sampai putus, aduh berlumuran darah seluruh jip” (Mangunwijaya, 1991: 60).

"Jadi jangan-jangan proyek kebanggannnya ini kelak justru menjadi senjata makan tuan, aduh sungguh mengerikan menakutkan mencemaskan hati Srikandi yang selamanya tidak pernah takut dan cemas" (Mangunwijaya, 1991: 152).

Tokoh lainnya yang juga diidentikkan dengan Srikandi adalah sopir wanita Iin. Hal itu terjadi, ketika mereka berdua meninjau tempat perkampungan Brojol yang secara tidak sengaja digusur oleh mega-proyek Iin. Sopir ini disebut Srikandi dalam konteks yang 
berbeda, yakni pada kegesitannya menyopir, dengan mengandaikannya seperti Setan Roban, juga dalam konteks barangkali wanita. (Mangunwijaya, 1991:153) Lengkapnya, berikut teksnya: "Menyusullah Mbak sopir mungil tetapi Srikandi itu ke dukuh pengungsian. Namun Mbakayu sopir yang mungil tetapi jantan itu tetap diam dalam seribu bahasa" (Mangunwijaya, 1991: 160). Pengandaian sopir dengan tokoh Srikandi memang dalam hal yang lain, tetapi substansinya sama. Posisi mereka sama-sama ambigu, diragukan kewanitaannya dan bersikap jantan. Aspek kontradiktif pada pengandaian itu ada pada masalah mungil dan Srikandi. Bisa jadi, teks ini ingin mengatakan bahwa untuk menjadi Srikandi, tidak harus bermodal 'kendi', bermodal mungil-mengacu pada tubuh, organ vital dan kekuatan jasmani pun tak apa dan bisa menjadi Srikandi, jika Sirkandi tersebut memang benar-benar sebagai perspektif ideal.

Dalam beberapa hal, muncul analogi tokoh Durga Umayi dengan tokoh-tokoh dalam mitologi atau tokoh masa lalu. Misalnya menyamakan Bung Karno seperti Tumenggung Wiroguna (dikenal alam kisah Rara Mendut). Teks lain menyebut kakak kembar dampit Iin yaitu Brojol identik dengan Dewa Basuki, dewa penguasa alam bawah tanah. Hal itu kaitannya dengan diri Iin yang disebut masih titisan atau keturunan Wisnu, yang berkuasa di Kayangan dengan Garuda Jetayu sebagai kendarannya. Teksnya: "Pada hakikatnya Brojol adalah keturunan Dewa Basuki, Raja Ular yang tinggal di bawah tanah, sedangkan Iin adalah keturunan Dewa Wisnu yang istananya di Kayangan dengan boeingnya Garuda Jetayu". (Mangunwijaya, 1991: 20)

Strategi teks dengan metode analogi itu mengangkat derajat tokoh tertentu tetapi dalam sisi lainnya terkesan 'melecehkan'. Semisal mengandaikan Bung Karno dengan Tumenggung Wiroguno. 'Pelecehan' itu tampak karena Wiroguna dalam kisah-kisah yang dikenal sebagai tokoh yang bereputasi buruk, yang suka merampas perempuan. Ada analogi Iin dan Brojol dengan dewa-dewa, di mana mereka dapat pula dikatakan sebagai kelas sub-ordinat, memberikan arti lebih pada posisi mereka.

Mengenai perbandingan yang terakhir ini, terdapat usaha untuk membalik konsepsi mitologi mapan. Hal itu tampak pada pengandaian Brojol sebagai Dewa Basuki penguasa alam bawah, sedangkan Iin sebagai titisan Wisnu penguasa alam atas. Pengandaian itu berdasar nasib yang sedang mereka lakoni. Kontradiksi itu akan terasa dengan mitologi bahwa bumi (dunia bawah) dianggap sebagai perlambang perempuan dan dikukuhkan sebutan Ibu Pertiwi. Untuk kaum lelaki diandaikan sebagai dunia atas dengan sebutan Bapak Angkasa. Mitologi tersebut memang menguasai jagat kosmologi 'Timur'. Anggapan pada tanah tumpah darah ini berbeda dengan beberapa bangsa di Amerika dan Eropa. Hal itu akan menemukan ketepatannya jika mengacu pada kosmologi 'Barat', ketika melihat Tanah Air sebagai Father Land, dengan sebutan Uncle Sam untuk Amerika Serikat. Mengenai pembalikan dan 'decentering' dengan model di atas sering kali dijumpai dalam beberapa teks dalam Durga Umayi.

\section{Melacak 'Jejak' Lakon Ruwatan dalam Durga Umayi}

Dalam dekonstruksi terdapat semacam metode pelacakan jejak, untuk menunjukkan bahwa sebuah teks bukanlah sebuah teks utuh tetapi tersusun dari teks-teks lainnya. Pelacakan jejak memang mengandaikan adanya teks lain yang tersembunyi dalam tataran teks yang terajut. Dalam Durga Umayi, terutama pada bagian Prawayang-nya, dapat dikatakan kisah yang terpaparkan di dalamnya mempunyai kesesuaian dengan pakem wayang purwa, tetapi ada juga yang tidak berkesesuaian bila dibandingkan dengan versi lainnya.

Perbedaannya terutama terletak pada posisi Dewi Uma. Dalam satu versi menempatkan Dewi Uma sebagai istri yang tidak patuh pada suami, dengan menolak ajakan Batara Guru untuk bersenggama di atas pelangi dengan menunggang Lembu Andini 
(Windardi, Panyebar Semangat, tanpa angka tahun). Dalam versi lainnya mengatakan Dewi Uma sebagai istri telah berkhianat, dengan bermain serong (Moelyono, 1977: 47). Begitu pula kisah yang terdapat dalam sastra Jawa Kuno Kidung Sudamala (Zoetmulder, 1994: 539). Hal serupa juga dalam pakem pedalangan lainnya, seperti Kakawin Partayajna, Smaradahana, Krsnakalantaka, Pakem Kandhaning Ringgit Purwa dan Pustakaraja Parwa. Lebih utamanya adalah di dalam Kitab Manikmaya, Kama Salah, Pakem Muwakala, Serat Centini dan Serat Paramayoga, yang semuanya bercerita tentang kelahiran Batara Kala. Lakon tentang proses kelahiran Batara Kala yang dimaksud sering digunakan dalam rangka ruwatan sengkala.

Dalam Durga Umayi, Prawayang-nya menunjuk pada cerita yang menempatkan Dewi Uma sebagai istri yang tidak patuh, yakni adanya penolakan Dewi Uma terhadap ajakan Batara Guru untuk bersanggama. Jadi merujuk pada pakem wayang purwa versi yang pertama (dalam Kitab Manikmaya dan Kama Salab). Kisah yang ada dalam Prawayang berkesesuaian dengan pakem itu. Hanya saja, bahasanya mengalami modifikasi sedemikian rupa, lebih merujuk pada kata-kata yang dipergunakan seorang dalang sebelum memasuki lakon yang sebenarnya. Istilah pedalangannya disebuat jejer dan suluk. Kisahnya berintikan proses perjalanan Dewi Uma dengan Batara Guru, sampai terjadinya sumpah serapah dari Dewi Uma pada Batara Guru, dan vonis yang dijatuhkan oleh Batara Guru terhadap Dewi Uma sebagai Batari Durga yang menghuni Setragandamayit.

Dalam cerita wayang, sebelum dan sesudah penggalan kisah dalam Prawayang, terdapat kisah yang melatarinya, yang berkisah tentang pertemuan Batara Guru dengan Dewi Uma. Begitu pula ada kisah lanjutan setelah berubahnya Dewi Uma menjadi Durga. Hal itu dimulai dari kisah mengenai Dewi Uma, hingga ia dipersunting oleh Batara Guru. Sementara itu, ada juga kelanjutan kisahnya, setelah Uma menjadi Durga, yang melibatkan anak-anak Pandudewanata (Pandawa). Dalam momen itu juga terdapat beberapa peristiwa fenomenal, dengan menitikberatkan pada peran Batara Guru sebagai penguasa Jagad Girinata.

Akan tetapi, Prawayang mengunggah cuplikan kisah mengenai accident dari perjalanan Dewi Uma dan Batara Guru. Fokus yang dipilih dalam penceritaannya mempunyai keterkaitan dengan isi Durga Umayi. Perlu pula dijelaskan bahwa yang diambil dalam teks-teks Durga Umayi dari kisah Prawayang-nya, bukanlah kisah wayang yang secara verbal mengadopsi kisah Uma dan Durga, tetapi lebih ditekankan pada substansi yang berisi semangat, ruh atau inti dari kisah itu, dengan mengejawantahkannya atau menafsirkannya dalam karakterisasi tokohtokohnya. Misalnya, momen perubahan Uma ke Durga diambil sebagai aspek dilematis dalam diri Iin. Dengan memberi penekanan bahwa aspek Durga diartikan 'dewi kejahatan' yang selalu bertarung dengan aspek Uma, yang diidentikan 'dewi kebaikan'. Pertarungan itu berlangsung dalam seluruh perjalanan hidup Iin, yang berperan sebagai 'sentral' dari tek-teks dan wacana yang terdapat dalam Durga Umayi.

Dalam teks Durga Umayi, kisah yang merujuk atau diidentifikasi sebagai awal perubahan Iin dari Uma menjadi Durga, adalah momen-momen ketika Iin ikut laskar pejuang, yang dalam sebuah pertempuran, ia berhasil memenggal kepala seorang tentara perwira Gurka.

"Tetapi bagaimana seandainya perwira Gurka tampan muda dari suku India yang tersohor jago-jago kelahi itu tahu kepalanya dipenggal oleh tangantangan perempuan? Oleh seorang Batari Durga? Ah, benarkan Iin Linda Pertiwi sekarang sudah menjadi pengejawantahan Batari Durga yang dulu Dewi Uma sakti sani santing cantik, istri Batara Guru penguasa kayangan itu?." (Mangunwijaya, 1991: 63)

Untuk selanjutnya, konsepsi DurgaUma itu menjadi semacam dualisme dalam diri Iin. Muncul semacam kekaburan atau ketidakjelasan pribadi Iin, apakah ia sebagai Uma -yang jelita-- atau sebagai Durga --sang pembunuh--, jika dibenturkan dengan konsepsi 
keutuhan sebuah pribadi. Seringkali persoalan dilematis ini ditegaskan dalam beberapa teks, yang memang menekankan pada konsepsi tersebut. Adapun keterpecahan pribadi dan jati diri yang diusung Durga Umayi, merupakan sebuah titik balik dari konsepsi tentang gagalnya strukturalisme, yang mengandaikan keutuhan dari setiap bagian-bagian dan unsur-unsur pembentuk keutuhan sebuah konstruksi.

"Dewi Uma yang cantik sakti sekaligus Durga yang jahat pembunuh dan penyebab malapetaka penyiksa manusia, ah jangan, jangan Tiwi harus menjalani peran Durga itu, inilah yang menyedihkan Tiwi bila malam-malam di tengah malam buta ia tidak dapat tidur dan terombang-ambing dalam peperangan batin." (Mangunwijaya, 1991: 64)

Pertanyaan dan pernyataan terus bermunculan mengenai dua konsepsi dilematis Uma-Durga tersebut, seperti penegasan: "apakah harus ada Dewi Uma-nya sekaligus ada Durga-nya?” (Mangunwijaya, 1991: 196). Dalam konteks dekonstruksi, hal itu disebut pengaburan sistem oposisi biner. Sebuah konsepsi yang mengandaikan tidak ada kejelasan antara posisi Uma dan Durga. Uma yang selama ini dipahami sebagai wakil kebaikan bercampur, bersenyawa, dan berkaitan dengan Durga yang merupakan wakil kejahatan.

Dalam kisah selanjutnya, bayangbayang sang Durga sering datang dan meneror Iin. Misalnya, ketika Iin menjalin cinta dengan seorang pemuda, Rohadi. Cinta yang dalam pengertian luas merupakan ruh dari kebaikan itu, selalu mendapatkan teror dari Sang Durga. Adapun teksnya sebagai berikut:

"Perempuan yang merana sedih merasa diri terkutuk sebagai Durga yang harus mengawini benih suaminya sendiri si Batara Kala. Alangkah ingin dan hasratnya si perempuan Tiwi menawarkan pengakuannya kepada Mas Rohadi, bukan sebagai pelampiasan nafsu, melainkan sebagai tanda terima kasih dan berutang budi kepada Mas Rohadi itu, akan tetapi setiap kali ia berkata pada dirinya: sekarang, ya sekaranglah, langsung Batara Kala mencambuknya." (Mangunwijaya, 1991: 119)

Kondisi itu sering terjadi, apalagi ketika Iin secara tidak sadar memerankan sebagai perempuan yang kejam terhadap anak-anak manusia. Dalam konteks ini, kesadaran bahwa dirinya sebagai pengejawantahan Durga kembali muncul. Durga seakan-akan bermainmain dalam ketaksadaran Iin. Misalnya, ketika dihadapkan pada dilema yang harus dihadapi dengan kejernihan berpikir dan kesadaran. Iin sepertinya harus bergulat dengan Durga dalam dirinya. Di antaranya ketika ia harus menggusur desa dan tanah dari abang kembar dampitnya, serta pada momen-momen, ketika ia sendiri merenungkan apa yang telah dicapainya, dalam kondisi real sebagai call girl dan spionase internasional. Dilema dan kontradiksi itu diungkapkan dengan jelas dalam teks berikut ini:

"Merenung berpikir menimbang bingung bimbang mengotak atik dan merancang apa sebaiknya, merenung menimbang-nimbang lagi bagaimana seyogyanya mengolah pertanyaan penuh dilema dan kontradiksi Durga Umayi..." (Mangunwijaya, 1991: 184)

Demikianlah pengaburan oposisi UmaDurga. Sementara itu, upaya pelacakan jejak di sini dipahami sebagai sebuah pembacaan terhadap penafsiran kembali pada konvensi atau substansi cerita lama, dengan memberi tekanan untuk membalikkan konsepsi yang sudah ada, dengan mengembalikan pada paradigma yang tidak tunggal. Jaringan teks Durga Umayi sendiri unik karena keseluruhan teks dalam novel sangat kontradikstif, yakni dengan sengaja membandingkan Prawayang dan isi. Namun, jika novel tersebut dibandingkan dengan salah satu versi wayang purwa lainnya, juga terdapat beberapa perbedaaan, seiring dengan kisah perubahan Dewi Uma menjadi Durga dan kemudian menjadi Umayi kembali.

Dalam Kitab Manikmaya, yang disadur 
Nanang Windradi dalam Panyebar Semangat, mengisahkan setelah Dewi Uma berubah menjadi Raseksi, Batara Guru mendapat wisik agar melihat istri selir dari Hyang Caturkanaka, Dewi Laksmi. Dewi Laksmi terkenal sangat cantik, dengan kecantikan dapat dikatakan kembar dengan Dewi Uma. Dengan kehendak Batara Guru, sebagai penguasa Jagad Girinata, sukmanya Dewi Laksmi disuruh pindah ke raga Dewi Uma, sedangkan sukmanya Dewi Uma dipindah ke raga Dewi Laksmi. Sebagai dewa tertinggi, setelah Hyang Tunggal, semua keinginan Batara Guru itu terkabul. Raga Dewi Uma yang di dalamnya berdiam sukma Dewi Laksmi, yang telah berubah menjadi Raseksi, dinamakan Batari Durga. Kemudian diutus ke Setragandamayit menemai benih Batara Guru, yaitu Batara Kala. Sedangkan raga Dewi Laksmi, yang di dalamnya berdiam sukma Dewi Uma, dinamakan Umayi dan tetap mendampingi Batara Guru, sebagai istrinya.

Mengenai lakon ruwatan seperti yang dinyatakan Nanang Windardi, terdapat dalam beberapa khasanah Jawa lama, baik dalam bentuk tembang macapat maupun gancaran, seperti dalam Serat Centini, Paramayoga, Pedalangan Ringgit Purwa dan beberapa khasanah lainnya. Hanya saja dalam khasanah lama itu konsep sakralitas begitu kental. Yang dipaparkan dan mendapat penekanan seputar pada masalah ritual sakral ruwatan murwakala, disertai dengan tata-aturan ruwatan.

Cerita berubahnya Dewi Uma menjadi Durga juga terdapat dalam sastra lisan Jawa Kuno, yaitu dalam Kidung Sudamala. Zoetmoelder menyebut kisah ini lebih menampilkan sifat kerakyatan dan tak ada latar belakang kraton (Zoetmulder, 1994: 539-540). Dalam beberapa bagian cerita ini mengambil dari versi wayang purwa yang menempatkan Dewi Uma serong, sehingga dikutuk Batara Guru menjadi Durga (Moelyono, 1977: 141). Kesan untuk menempatkan Batara Guru sebagai tataran yang tidak tersentuh sangat kuat sekali dalam versi ini, karena teksnya menunjukkan kemarahan dan kesaktian Batara Guru, dan menempatkan Dewi Uma sebagai pihak yang salah dan kalah.
Bisa jadi Kidung Sudamala merupakan varian dari cerita wayang Purwa versi yang lain dari pakemnya tetapi karena melewati proses pelisanan terjadi banyak versi dan perubahan.

Pengisahan Kidung Sudamala merupakan kelanjutan dari episode perubahan Dewi Uma menjadi Durga, tetapi penyebutan Durga di sini tidak ada. Pasalnya, Kidung Sudamala berkisah tentang Dewi Uma yang hidup dalam wujud makhluk jahat dengan nama Ra Nini (bukan Durga!) di pekuburan Ganda Mayu. Cerita ini ditengarai merupakan lakon carangan dari kisah wayang purwa pakemnya, karena masuknya unsur punokawan, yaitu Semar, dalam kisah tersebut.

KidungSudamaladalam perkembangannya, dipakai dalam reportoar wayang dengan lakonlakon ruwat (Zoetmulder, 1994: 541). Nama tempat yang disebut juga berlainan dengan yang ada dalam wayang Purwa. Seperti Gandamayu dan Prangalas. Sepertinya unsur kejawaannya sangat terlihat, termasuk pada unsur Semar dan penamaan Kidung Sudamala sendiri, yang berarti nyanyian untuk mengurangi bahaya; kidung untuk ruwatan yang merupakan tradisi buang sial dalam budaya Jawa, seperti yang telah dituturkan.

Pelacakan jejak ini bisa dipahami sebagai sebuah upaya untuk menjadi 'jejakjejak' dari konstruksi teks yang berupa realitas dan dianggap 'terberi', sekaligus mengaburkannya. Selama ini 'realitas' yang berserak itu, terbagi dalam oposisi-oposisi biner yang saling beroposisi, saling berhadapan dan melemahkan, sebagaimana baik-buruk, kecil-besar, juga Durga-Uma. Ternyata, oposisi biner itu merupakan aspek dilematis yang selalu tarik-ulur, tidak ada yang kalah-menang atau saling mengungguli. Jadi oposisi biner itu berjalan dalam proses differance. Terdapat perbedaan penafsiran dalam penerimaan yang terus-menerus, sesuai dengan konteks ruang dan waktu. Jadi, tiada pemaknaan final, dan posisinya selalu tertunda.

Terkait dengan lakon ruwatan ini, teksteks Durga Umayi mempunyai tendensi dengan pengaburan oposisi biner serta peniadaan pusat atau decentering, dengan membaca 
kembali konsep dewa yang telah terpahami dan terdefinisikan selama ini. Semacam mengembalikan gambaran dewa-dewa dalam realitas tertinggi manusia, dalam porsinya yang wajar. Konsepsi dewa yang cukup 'tinggi' dalam dunia wayang direduksi dalam kaitannya dengan keadaan batin manusia, yang merupakan dunia halus, yang termasuk bagian manusia juga.

\section{Kesimpulan}

Durga Umayi mengandung banyak teks yang menunjukkan adanya pengaburan sistem oposisi biner. Sebenarnya hal itu tidak hanya berlaku dalam wacana wayang saja, tetapi juga pada wacana gender dan sejarah Indonesia mutakhir yang juga 'dimainkan'. Adapun, operasionalisasi oposisi biner yang ada dalam teks-teks itu tidak hanya dihadirkan seperti yang selama ini dikenal, melainkan dengan pengaburan, pembalikan dan serangkaian upaya dekonstruksi lainnya. Strategi pembalikan dan pengaburan oposisi itu terkesan menyaran pada tendensi yang tidak hanya terdapat pada muatan teks Durga Umayi saja, melainkan pada tek-teks lain, meliputi bangunan ideologi, realitas sosial, kulktural dan teks-teks lainnya.

Dalam sebuah telaah struktur, oposisi biner menduduki tempat istimewa. Seperti halnya dalam kajian bahasa Saussurian, kajian antropologi Levi-Strauss dan beberapa kajian struktural lainnya. Model kajiannya mendasarkan diri pada model oposisi biner, karena oposisi biner dan relasinya itulah yang menopang sebuah bangunan teks secara utuh. Hanya saja, dalam perkembangannya di antara kedua oposisi yang berseberangan dan berbeda itu saling melemahkan, apalagi jika hubungannya tidak lagi hubungan horisontal, melainkan vertikal yang mengarah pada tataran hierarki. Adapun, jika ditarik pada konstruksi yang lebih luas, maka yang terjadi adalah 'penindasan' dan 'ketidakadilan' pada salah satu posisi, karena ada satu posisi yang dilemahkan dan ada satu posisi lain yang diistimewakan. Kenyataan itulah yang dibenahi dan dikritik oleh kalangan pos-struktural, karena kenyataan itu merupakan salah satu kekurangan strukturalisme, selain beberapa kekurangan lainnya.

Dalam novel Durga Umayi pemanfaatan model oposisi biner sekaligus mengaburkannya semata-mata dalam rangka menutup, mengkritik, sekaligus membenahi kekurangan itu. Dalam teks wayang, upaya pengaburan itu sebagai kritik ideologis. Hal itu karena di luar teks Durga Umayi berkembang teks-teks yang mengarah pada sebuah nuansa yang sangat lain, berbeda dan beroposisi dengan Durga Umayi. Jika teks wayang di luar teks dianggap sakral (terutama yang berkaitan dengan pementasan lakon ruwatan), hal sebaliknya terjadi pada teks Durga Umayi, karena teks-teks yang ada sangat profan. Pemaparan yang ada memang mengarah pada pelacakan jejak tersembunyi dalam teksteks Durga Umayi, dan jejak itu juga terpendam dalam hubungannya dengan artefak-artefak budaya yang berserak.

Pengaburan oposisi biner itu pun berlaku dalam dunia mitologi yang menguasai memori kolektif. Misalnya, dalam Durga Umayi digambarkan adanya pasangan yang beroposisi, yaitu Brojol dan Iin. Brojol lakilaki, Iin perempuan. Hanya saja, ada sebuah upaya pembalikan terhadap posisi yang selama ini dikenal, sebab sudah menjadi lazim dari kedua pasangan yang beroposisi itu salah satunya menempati posisi previliese dan satunya dilemahkan. Seperti diketahui, dalam alam mitologi Jawa, lelaki selalu digambarkan sebagai penghuni alam atas, dengan pengandaian sebagai Bapak Angkasa, sedangkan perempuan sebagai alam bawah dan bumi, dengan sebutan Ibu Pertiwi.

Dalam Durga Umayi konsepsi itu dibalik dan dikaburkan dengan menempatkan posisi yang istimewa itu berada pada posisi yang sebaliknya. Hal ini selaras dengan metode dekonstruksi Derrida, yang ditegaskan Culler dalam landasan teori. Pembalikan mitologi itu dengan mengandaikan bahwa In sebagai penjelmaan dari titisan Dewa Wisnu yang berkendaraan Garuda Jatayu, yang melambangkan dunia atas. Adapun, Brojol sebagai pengejawantahan Dewa Basuki, penguasa alam bawah. 
Selain oposisi biner antara yang atasbawah, sakral-profan, dalam Durga Umayi juga terdapat pengaburan oposisi biner dengan mengaburkan posisi antara perempuan dan lakilaki. Tak urung, pengaburan ini juga memiliki maksud atau makna tersembunyi. Dalam konteks gender, maka pengaburan itu sebagai upaya perlawanan, untuk melawan dominasi patriakhal dan mengugat konstruksi sosiokultural bahwa peran perempuan memang peran terberi. Jalan yang ditempuh cukup menarik, karena dengan mengembalikan konstruksi itu pada asal penciptaan manusia, dengan merunut pada siklus yang sama sekali purba dan alami, yaitu dengan mengembaklikan peran perempuan sebagai makhluk yang melahirkan anak manusia, tanpa sederet pretensi untuk melemahkan yang merupakan rekayasa sosial dan budaya yang telah berjalan berabad-abad.

Pengaburan itu juga terdapat pada oposisi biner antara besar-kecil, pusat-pinggiran, terutama terhadap tokoh-tokoh besar, sejarah mapan dan lain-lainnya. Semua oposisi biner yang disertai dengan pengaburannya itu sudah termatub dan teraplikasikan dalam pembahasan dekonstruksi dalam Durga Umayi ini, karena hal itu merupakan ruh utama dari cara baca dekonstruksi. Bisa pula dikatakan, hal itu bukan hanya sebagai sebuah kehadiran begitu saja melainkan memiliki muatan teks yang bersifat sangat politis, sebagai sebuah strategi yang memiliki tujuan untuk mengubah sebuah posisiposisi yang selama ini dianggap telah mapan. Ada anggapan, bahwa strategi pengaburan oposisi biner itu tidak sekedar sebagai kritik ideologi tetapi juga sebagai perlawanan pada hegemoni pemaknaan tunggal, juga sebagai perayaan keberagaman dan heterogenitas.

Akhirul kalam, teks-teks wayang dalam Durga Umayi dapat ditarik pada suatu rancang bangun bahwa dekonstruksi dipahami sebagai cara baca untuk melihat konstruksi tradisi yang selama ini terlembaga dan mapan. Dengan asumsi, jika tidak dikritisi atau dibongkar hubungan-hubungan strukturalnya menjadi penghalang untuk peneloran gagasan, ide dan pemikiran lebih lanjut yang sesuai dengan semangat zaman, juga agar warisan itu tidak lekas menjadi fosil.

\section{Daftar Pustaka}

Allen, Pamela. 1996. "Kebangsaan dan Pencitraan dalam Tiga Roman Mangunwijaya". Jakarta : Kalam, Edisi 8. Appignanesi, Richard dan Chris Garrat, 1999. Mengenal Postmodernisme, For Beginners. Bandung : Mizan.

Awuy, Tommy F. 1994. "Menolak Logosentrisme, Merayakan Perbedaan". Jakarta : Kalam, Edisi 1.

Bertens, K. 1994. Filsafat Barat Abad XX Perancis. Jakarta : Gramedia.

Culler, Jonathan. 1983. On Deconstruction: Theory and Critism After Strukturalism. London : Routledge and Kegan Paul.

Derrida, Jacques. 1982. Margins of Philosophy. Brighton : Harvester Press.

1981. Positions. Chicago : Alphonso Press.

Hogjakarta : Bentang.
Jantu Marx.

Faruk.. 1994. Sosiologi Sastra. Yogyakarta : Bentang.

1999. Hilangnya Pesona Dunia. Yogyakarta : YUI.

Fox. Nicolas. 1995. "Intertextuality and Writing of Social Research." Electronic Journal Sociology (1995).

Hardiman, Budi F. 1994. "Ilmu-ilmu Sosial dalam Diskursus Modernisme dan Pascamodernisme". Jakarta : Ulumul Quran (Suplemen).

Hardjowirogo. 1989. Sejarah Wayang Purwa. Jakarta : PN Balai Pustaka.

Harland. Richard. 1987. Superstructuralisme, The Philosophy of Structuralism and PostStructuralism. London : Methuen.

Jabrohim (ed.). 1994. Teori Penelitian Sastra. IKIP

Muhamadiyah Yogyakarta : Masyarakat Poetika Indonesia.

Junus, Umar. 1992. "Durga Umayi dan Kalimat Panjang”. Basis, Maret Nomor 4. .1992. "Kademer ADALAH merdeka 
YANG bukan merdeka, Fenomena Durga Umayi". Basis, Juni Nomor 6. 1994. Kebudayaan Jawa. Jakarta : Balai Pustaka.

Leitch, Vincent B. 1983. Deconstructive Criticism : An Advanced Introduction. London, Melbourne : Hutchinson.

Manuaba, I. B. Putera. 1996. Durga Umayi, Kajian Berdasarkan Strukturalisme Genetik. Yogyakarta: Tesis S2 Program Pasca Sarjana UGM.

Mangunwijaya, Y. B. 1991. Durga Umayi. Jakarta : Grafiti.

-1996. "Saya Cuma Pastur Desa" (Wawancara Tentang Disiplin Pendidikan, Hadiah Nobel dan Korupsi). Matra, Desember 1996.

McHale, Brian. 1991. Postmodernist Fiction. London and New York: Routledge.

Mulyono, Sri. 1977. Wayang dan Karakter Manusia. Jakarta : Yayasan Nawangi dan PT Inaltu.

Newton, KM. (terj. Soelistia, ML). 1991. Menafsirkan Teks. Semarang : IKIP Semarang Press.

Norris, Christopher. 1982. Deconstruction: Theory and Practice. London : Methuen.

Piliang, Yasraf Amir. 1998. Sebuab Dunia yang Dilipat. Bandung : Mizan.

1999. Hiper-Realitas Kebudayaan. Yogyakarta : LKiS.

Poerbatjaraka, R M Ng. 1964. Kepustakaan Djawi. Jakarta : Djambatan.

Pujiharto. 2010. Perubahan Puitika dalam Fiksi Indonesia. Yogyakarta: Prodi S2 Ilmu Sastra UGM dan Elmatera.

Sumartana, Th dkk (ed.). 1995. Mendidik Manusia Merdeka Romo YB Mangunwijaya 65 Tahun. Yogyakarta : Interfidei.

Supadjar, Damardjati. 2001. Nawang Sari. Yogyakarta : Pustaka Hidayah.

Sindhunata (ed). 1999. Menjadi Generasi Pasca Indonesia, Kegelisahan YB Mangunwijaya. Yogyakarta : Kanisius.

Said. Edward, W. 1995. Kebudayaan dan Kekuasaan, Membongkar Mitos Hegemoni Barat. Bandung : Mizan.
Selden, Raman. (terj. Rahmat Djoko Pradopo). 1991. Panduan Pembaca Teori Sastra Masa Kini. Yogyakarta : Gajah Mada University Press.

Sutrisno, Mudji. 1991. "Gugatan Perjalanan di Arsip Bangsa”. Kompas, 14 Juli 1991.

Sugiharto, Bambang I. 1996. Postmodernisme Tantangan bagi Filsafat. Yogyakarta : Kanisius.

Teeuw, A. 1980. Tergantung Pada Kata. Jakarta : Pustaka Jaya. 1984. Sastra dan Ilmu Sastra Pengantar Teori sastra. Jakarta : Pustaka Jaya.

Tim Penyusun Lembaga Javanologi. 1996. Ruwatan Murwakala, Suatu Pedoman. Yogyakarta : Duta Wacana University Press.

Windradi, Nanang. "Sang Hyang Bathara Guru". Surabaya, Panyebar Semangat tanpa angka tahun.

Zoetmulder, PJ. (terj. Dick Hartoko). 1994. Kalangwan, Sastra Jawa Kuno Selayang Pandang. Jakarta : Djambatan. 